\title{
The meteorological framework and the cultural memory of three severe winter-storms in early eighteenth-century Europe
}

\author{
Christian Pfister • Emmanuel Garnier • Maria-João Alcoforado • \\ Dennis Wheeler · Jürg Luterbacher • Maria Fatima Nunes • \\ João Paulo Taborda
}

Received: 19 August 2008 / Accepted: 19 November 2009 / Published online: 7 January 2010

(C) Springer Science+Business Media B.V. 2009

\begin{abstract}
Three violent eighteenth-century storms that ravaged the North Sea area (1703), western central Europe (1739) and Portugal (1739) are investigated from the point of view of their meteorological setting, their socio-economic impact, and whether and by what means they secured an enduring place in the cultural memory. The evidence draws on individual narrative sources such as chronicles and poems, and institutional sources such as ship's logbooks and state-organised 'windthrow' inventories of tree loss. Each of the three storms had socio-economic impacts that could be described as 'war-like' in the damage caused to buildings and the destruction of forests. The "Great Storm" of December 1703 jeopardized English naval supremacy in the War of the Spanish Succession by sinking a number of Royal Navy ships and taking the life of more than 8000 seamen. In January 1739 two similarly destructive storms swept over mainland Europe. The cultural memory of the three events here considered was however strikingly different. The
\end{abstract}

\footnotetext{
C. Pfister $(\varangle)$

Oeschger Center for Climatic Change Research/Institute of History, University of Bern, Unitobler, 3000 Bern 9, Switzerland

e-mail: pfister@hist.unibe.ch

E. Garnier

Laboratoire des Sciences du Climat et de l'Environnement, UMR CEA-CNRS,

CE Saclay, L'Orme des Merisiers Bat 701,

91 191, GIF-sur-YVETTE, France

e-mail: egarnier.cea-cnrs@orange.fr

E. Garnier

Centre de Recherche de l'Histoire Quantitative, UMR CNRS University of Caen, 14032 Caen Cedex, France

M.-J. Alcoforado

Centre for Geographical Studies, University of Lisbon, Alameda da Universidade, 1600-214 Lisboa, Portugal

e-mail: mjalc@fl.ul.pt
} 
sequence of storms in January 1739 though being the most protracted of the last centuries, and well-chroniceled, did not persist in the collective memories of those in France, Switzerland and elsewhere who experienced them. Likewise, the "Great Storm" was quickly forgotten on the continent, whereas its memory remained deeply rooted in England through the writings of Defoe (1704). In Portugal the 1739 storm won a lasting place in the country's cultural memory owing to two poems that it inspired. Furthermore, it was recorded in the Kingdom's official newspaper, in the astronomical prognoses and in written records of the Old Regime's cultural elite.

\section{Introduction}

"France has never experienced such a disaster! No event of a comparable severity is known in the sources for at least four centuries". Such was the unequivocal claim of the great French climate historian Le Roy Ladurie (Source S22), when he was invited to comment on the chaos created by the winterstorms "Lothar" (26 Dec. 1999) and "Martin" (27 Dec. 1999) (Wernli et al. 2002). Both storms did indeed cause extreme damage: 88 people died, 138 million $\mathrm{m}^{3}$ of timber were blown down, 400,000 telephone and power supply lines were out of order and 120 distribution pylons were destroyed leaving 2 million people without electricity (Source S23). The insured losses were estimated at 5.5 billion Euros (Schweizerische Rückversicherungs-Gesellschaft 2007). This unexpected vulnerability of modern technology traumatized the French public leaving them with a feeling of powerlessness and leading them to put the blame for the disaster on the state. Both the media and politicians stressed the exceptional character of the "storm of the century" in order to allay public anxieties. Le Roy Ladurie's assertion served to revise public opinion on climate change. If the storms were unprecented, as he declared, the most likely explanation thought to be the hitherto disregarded Greenhouse Effect. However, subsequent historical research detected earlier analogues to "Lothar" and "Martin" revealing that Le Roy Ladurie was mistaken (Corvol 2005) and that France, Switzerland and southern Germany had been ravaged between 14th and 18th January 1739 by a series of similarly violent

D. Wheeler

Faculty of Applied Sciences, University of Sunderland, Sunderland SR1 3PZ, UK

e-mail: dennis.wheeler@sunderland.ac.uk

J. Luterbacher

Department of Geography, Climatology, Climate Dynamics and Climate Change, Justus Liebig University of Giessen, Senckenbergstrasse 1,35390 Giessen, Germany

e-mail: Juerg.luterbacher@geogr.uni-giessen.de

M. F. Nunes

History and Philosophy of Science Research Unit, University of Évora, Évora, Portugal

e-mail: mfn@uevora.pt

J. P. Taborda

Escola Secundária Gabriel Pereira, Évora, Portugal

e-mail: joaotaborda@hotmail.com 
windstorms. This episode is here named the "Hilaire-Prisca" event after the saint's days of the first ("Hilaire", 14th January) and the last day of its occurrence ("Prisca", 18th January). This continues the century-old practise of naming historic storms and floods on the North Sea coast after the saint's day of their occurrence (e.g. St. Elizabeth's Flood of 19th Nov. 1414) Gottschalk (1971-1977). Today, the German Weather Services (DWD) name cyclones in alphabetic order respecting, however, gender standards by alternating between female and male names (Source S28). Despite the copious entries in private diaries, the windstorm series "Hilaire-Prisca" failed to leave a trace in the "official" historical memory of France or in that of the Swiss cantons: a feature which accounts for the recent amnesia that coloured descriptions at the turn of the millennium.

The episodes of "Lothar-Martin" and "Hilaire-Prisca" raise two issues. On one hand, there seem to be significant gaps in our knowledge of the chronology of European storms even for western Europe as recently as the eighteenth century. Early work by Lamb and Frydendahl (1991) has not been followed up and our detailed understanding is restricted to case studies of the most recent decades such as "Vivian" (1990), "Lothar" (1999) (Münchener Rück 1993; Schraft et al. 1993; Schüepp et al. 1994; Wernli et al. 2002; Erb et al. 2004; Ulbrich et al. 2009) and "Kyrill" (Fink et al. 2009). On the other hand, it is pertinent to enquire why a series of extreme storms such as the "Hilaire-Prisca" did not register in the cultural memory. This failure is perhaps yet more remarkable when it is recalled that the record of the most severe floods is possibly almost complete in the traditional historiography of both countries (Champion 1864; Amberg 1890).

Considering those two issues demands a twofold approach. On the one hand, there is the meteorological context, with its inevitable spatial dimension that defines its trajectory and geographical range; this includes also the immediate consequences and impacts of the "Hilaire-Prisca" winterstorm series, all of which need to be established as part of the evidence base. On the other hand, the loss of memory needs to be explained taking into account both the vulnerability of the affected societies and the cultural and political context in which such extreme events were recorded.

Over the past two decades scholars have increasingly come to accept that "natural" disasters should be understood as both physical events and social and cultural occurrences (Mauch 2009). Natural forces become disastrous only within given social and cultural frameworks. "It is society where disasters occur conditioned by its economic and cultural orders as well as by its political structures" (Mauelshagen 2009). Significantly, the second IPCC Working Group II Report is devoted to "Impacts, Adaptation and Vulnerability" (Parry et al. 2007).

With regard to the loss of historical memory, the crucial dimension is culture. Socio-economic structures and culture frameworks in the past are known to be regionally and locally highly diverse, which makes generalisations difficult. To highlight the differences, two other severe eighteenth century windstorms are included in this analysis of which the historical memory was well preserved: in the litany of storms that have at various times struck the British Isles, that of December 1703 has gone down in history as "The Great Storm" and has assumed an enduring significance (Lamb and Frydendahl 1991). The other example is from Portugal where a notable event, here denoted as the "Barbara" storm after the saint's date of its occurrence (4th December 1739) is well-chronicled. Besides its meteorological 
framework and socio-economic impacts "Barbara" is noteworthy from a cultural perspective, because this storm was described in two poems (see Sections 3.3 and 4.3). By covering both the physical and the cultural dimension of extreme events, this paper meets the comprehensive demands of 'Historical Climatology' as described in Pfister (2001).

This contribution presents in the following section both a review of scientific literature on storms in Europe over the past 500 years and hints at an immense volume of literature describing some key references in the fields of cultural history, cultural memory and historical disaster research. The third section deals with the meteorological framework and the impact analysis of the "The Great Storm", "Hilaire-Prisca" and "Barbara", each preceded by a survey of the sources. It is important to note that documentary evidence is the only source that is directly related to the socio-economic impacts of rare but significant disasters in the period prior to the organisation of instrumental network observations (Brázdil et al. 2005) and in that important sense differs from other 'proxy' sources such as tree rings and ice cores. This section is concluded by a comparative discussion of the three events. Section 4 focuses upon the issue of cultural memory and mirrors the preceding one in the sense that each of the three events is reviewed and summarised in a fourth comparative subsection. The conclusion puts the results of the "meteorological" and that of the "cultural" section in a comparative context and identifies new research challenges.

\section{Review of literature}

The state of research on pre-instrumental "historic" storms is geographically unbalanced. The most important text published on storm activity in the area of the British Isles is that by Lamb and Frydendahl (1991) in which they identify and describe all known major events over the past Millennium. More recently, evidence about severe storms over the British Isles is available from the English press in the form of an internet compilation (Source S1). In addition to the impressive collection on storm surges, evidence for the Dutch and German coast (Gottschalk 1971-1977) is available for The Netherlands from about 1400 to 1625 (de Kraker 2005). De Kraker (1999) also used data from accounts of dikes protecting the polder region in northern Flanders to trace the occurrence of high tides and storms in the past millennium. Brázdil and Dobrovolný (2000, 2001), Dobrovolný and Brázdil (2003) and Brázdil et al. (2004) investigated in detail the frequency and severity of windstorms during the past millennium on the territory of the present Czech Republic. Elsewhere in Central Europe severe storms were investigated through the Swiss National Research Program (NRP) 31 (Pfister 1998), while Schiesser et al. (1997) analysed the record of Zürich from 1864 until 1993 in order to obtain a 130 year long record of days with windspeed estimates or measurements equivalent to Beaufort 7, 8 and 9. Storm damage to forests in Switzerland from 1858 to 2007 was investigated by Usbeck et al. (2010). The winterstorms "Vivian" and "Lothar" prompted a wave of activity summarised in Schüepp et al. (1994) and WSL and BUWAL (2001) while, more recently, Rohr (2007) provided a cultural historical analysis of extreme events 
in Medieval Austria which included severe windstorms. Elsewhere the picture is sketchy further back than two centuries.

For more recent times, Bärring and von Storch (2004) studied Scandinavian storminess from about 1800. Matulla et al. (2008) studied European storminess from the late nineteenth century to the present. Bärring and Fortuniak (2009) analysed southern Scandinavian storminess from 1780 to 2005 and analysed the links to the interdecadal variations in the NW Europe-North Sea region. Finally, Wang et al. (2009) investigated the trends and variability of storminess in the Northeast Atlantic Region covering the period 1874-2007.

In France, research into historical climate has been slow and for a long time was the sole domain of the geographers (Doll 1991; Husson and Weisrock 2000) but the shock of "Lothar" and "Martin" launched a wider search for documentary evidence and data. However, the resulting synthesis (Corvol 2005) is incomplete and does not take into account the totality of the French territory, nor does it provide a complete synthesis of the storms since 1500. In Portugal, weather and climate were more popular topics in social and economic history, particularly when related to floods in Mediterranean agricultural societies. Critical editions of historical sources have recently been published (Miranda 2005; Lisboa et al. 2002-2005), and several geographers have written accounts of disastrous floods of the twentieth century (Amaral 1968; Daveau et al. 1978; Roxo and Ventura 1986; Azevêdo et al. 2004). In the maritime setting, studies of ships' logbooks for the period 1750-1850 undertaken in the CLIWOC project (Climatological Database for the World's Oceans) have shown the value of such material as a source of reliable climatic data and storm information (Garcia-Herrera et al. 2005a, b) and have cast a new light on storminess in the late seventeenth century in Wheeler and SuarezDominguez (2006) and Wheeler et al. (2009).

Reviews of the cultural dimension of disaster perception, disaster memory and historical disaster research are necessarily fragmentary. The notion of cultural history has developed since the 1980 within several national historiographical traditions such as the New Cultural history in the Anglo-Saxon world (Burke 1997), Kulturgeschichte in Germany (Daniel 2006) or the histoire culturelle in France (Poirrier 2004) and história da cultura científica in Portugal (Nunes 2004). The issue of "cultural memory" as an interdisciplinary approach for the study of cultural commemoration was framed by Jan Assmann (1992) following the works by Pierre Nora (1997) whose theme was the "sites of memory" and Maurice Halbwach's (1950) themed works on "collective memory". Whereas the collective memory is based on oral tradition, shared, passed on and also constructed by the group, often the family, the "cultural memory" should be understood as a social long-term memory based on written and material sources. But nature-induced disasters have remained long invisible in historiography. Traditional historians too often avoid any debate on the role of "nature" and disasters were long considered to be ephemeral in character and without any lasting consequences for society (Pfister 2009). By the late 1990s historians had already begun to recognise the importance of the environmental influences and historical disaster research developed rapidly (Juneja and Mauelshagen 2007; Schenk and Engels 2007) but it needed the experience of the disaster-ridden decade of the opening years of the new century, in particular of the Sumatra-Andaman tsunami (2004) and Hurricane Katrina (2005), to initiate a general change of opinion. 


\section{The meteorological framework and impact analysis of the three winterstorms}

\section{1 "The Great Storm” of 7/8 December 1703}

In the litany of storms that have at various times struck the British Isles, that of early December 1703 has gone down in history as "The Great Storm". On the continent, where the Gregorian style was in use, the storm is dated to 7th and 8th December whereas in England, which still clung to the Julian style, the known dates are 27th and 28th November. The epithet 'great' results, in part, from its undoubted severity. It results also from the social, political and cultural milieu in which it took place in England. Many first hand accounts of the storm have been gathered together and published by the political commentator Daniel Defoe (1704) in which he provides a matchless collection of descriptions from across England with which a clear picture of the storm and of its consequences can be garnered. In part at least it is this remarkable document that has allowed the memory of the storm to endure, aided perhaps by its occurrence at a time of war when remedial measures might be more difficult to initiate, the resources being demanded elsewhere.

The meteorology of the storm has been reviewed in Lamb and Frydendahl (1991) and by Wheeler (2003) who draws on information contained in ships' logbooks of the period. Wheeler and Suarez-Dominguez (2006) have already suggested that these decades were marked by an unusual degree of storm and gale activity in the latitudes of the British Isles and Wheeler's (2003) paper offers cogent evidence that the period between late November and early December of 1703 was one of persistent and increasingly violent storm activity. Indeed, for the days immediately preceding the arrival of the 'Great Storm' Defoe (1704) noted:

"24th [4th Dec] It had blown exceeding hard, as I have already observed, for about fourteen days past; and that so hard, that we thought it terrible weather:

Several stacks of Chimnies were blown down, and several Ships were lost, and Tiles in many Places were blown off from the houses, and the nearer it came to the fatal 26th of November, the Tempestuousness of the weath'r increas'd. On the Wednesday Morning before, being the 24th of November, it was fair weather, and blew hard; but not so as to give any Aprehensions, till about 4 o'clock in the Afternoon, the Wind increased, and with Squalls of Rain and terrible Gusts blew very furiously.

The collector of these sheets narrowly escap'd the Mischief of a Part of a house, which fell during the Evening of the Day of the Violence of the wind: and abundance of Tiles were blown off the houses that night; the wind continued with Universal violence all the next day and night; and had not the Great Storm followed so soon, this had pass'd for a Great Wind."

On 6th December this storm had moved away to the north-east, and a frontal wave was active over northern France. Towards midnight of 6th into 7 th, the storm was already evident over western Wales. Moving eastwards at about 40 knots $(74 \mathrm{~km} / \mathrm{h})$, it reached south-east England and Belgium in the early hours of 7 th December. Defoe observed, 'about 10 o'clock our barometers informed us that the night would be very tempestuous. The mercury sunk lower than ever I had observed it.' It was during this night that so much damage was done on land and at sea. The winds scarcely abated on daybreak, and continued strong, but from a more northerly quarter as 
the cyclone's centre moved swiftly to the north-east. This centre of the cyclone passed over Midland England (Fig. 1), leaving the most populous part of the country exposed to the worst consequences of the westerly winds on its southern flanks. In its wake was a trial of loss of life and property that is so vividly described by Defoe's accounts. Besides England the "Great Storm" also ravaged northern France, Belgium and Holland from 4 A.M. Around noon it crossed northern Germany, at 3 P.M. it struck Denmark and southern Sweden. The following morning it reached the eastern coast of the Baltic. Defoe (1704) described the storm as "The greatest, the longest in duration, the widest in extent, of all the Tempests and storms that history gives any account of since the Beginning of time" (p. 14). London looked and felt, as many observers noted at the time, like a city in the aftermath of a battle (Hamblyn 2003).

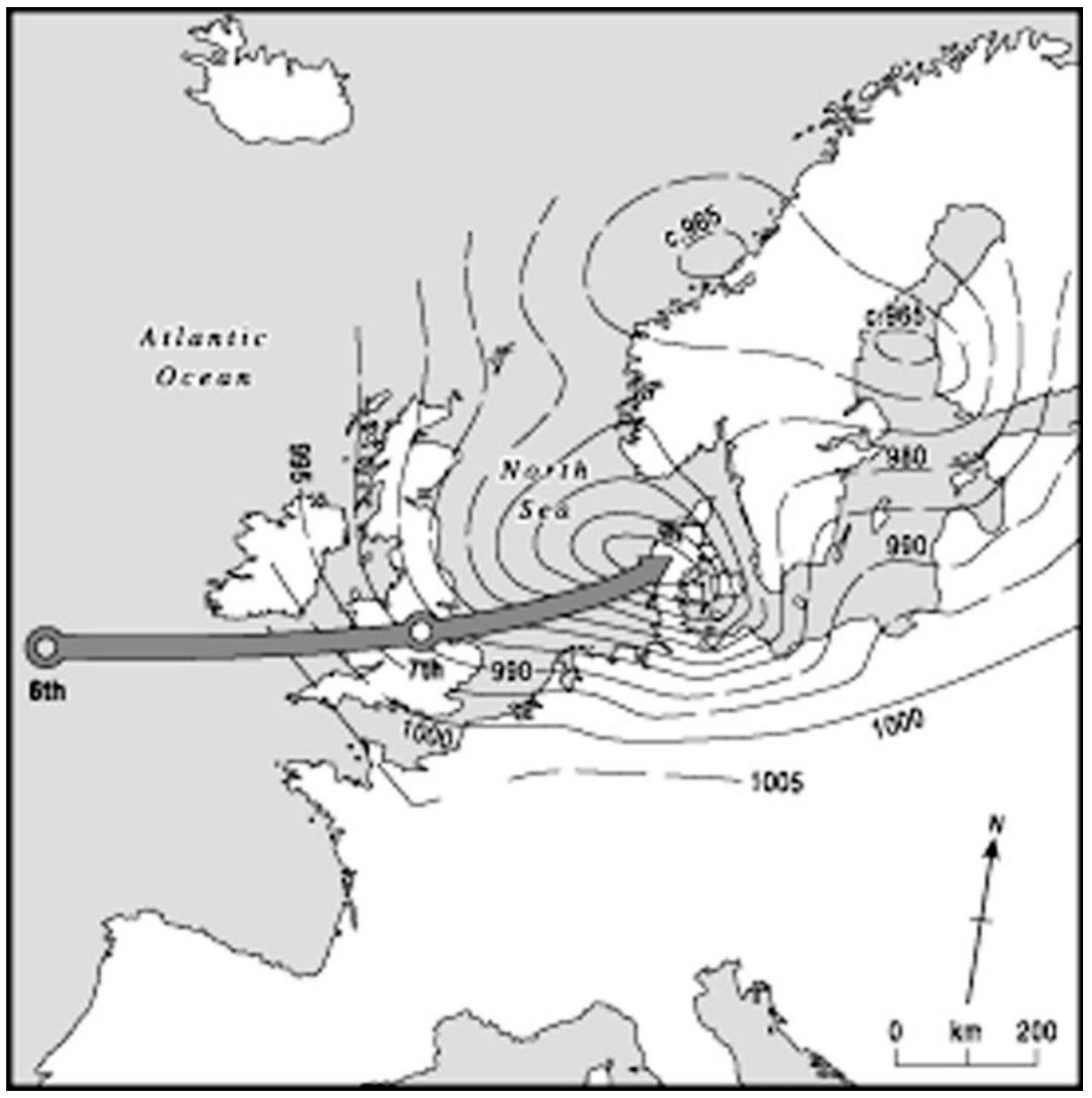

Fig. 1 Synoptic summary of "The Great Storm" of December 1703 in England (after Lamb and Frydendahl 1991) 
The crescendo of storm activity described by Defoe created the fateful situation that caused so many vessels to founder in the English Channel. The persistent westerly winds of late November and early December not only hastened homecoming trading ships along the Channel, it also hindered those wishing to move down-Channel against the prevailing winds. These included not only the usual merchant ships but also Royal Navy vessels and by early December 1703 the Channel was full of ships waiting to off-load goods or take on supplies for embarkation. It was on this crowded scene that the storm was visited. On that night thirteen Royal Navy ships and an unknown number of merchant vessels were lost. Several thousand sailors perished as ships were overcome by the storm or destroyed on the notorious sandbanks of the English Channel. There is not scope here to describe the full range of damage, consequences and loss of life in southern England but Brayne (2002) and, of course, Defoe (1704) provide comprehensive reviews and the former suggests the death toll to have been between 8,000 and 15,000 souls (see also Démarée and Muir-Wood 2009).

The damage to buildings was extensive across southern England. Between Cornwall in the west and Kent in the east, and as far north as Northamptonshire churches were unroofed of their lead, spires destroyed, stained glass windows blown in and whilst damage to secular buildings was less comprehensively narrated, it can be inferred to have been at least as extensive, especially amongst the less-soundly constructed dwellings of the poorer classes (Brayne 2002). Sources from the Low Countries detail that people were lifted up, houses stripped of their roof, steeples and windmills were blown down, vessels thrown on the beach and destroyed. Many dikes were badly damaged. A witness in s'Hertogenbosch compared the impact of the "Great Storm" with that of artillery fire during the recent siege of the town (Démarée and Muir-Wood 2009).

Many accounts of the time describe the event as a 'hurricane'. Most famous amongst these being that by John Evelyn (1706) who wrote "so many thousand goodly Oaks subverted by that late dreadful hurricane." The ships' logbooks contain many descriptions of the storm and Wheeler (2003) has already reviewed mariner's weather vocabulary for this event and it is noteworthy that so few seamen, most of whom perfectly understood its tropical connotation, used the term 'hurricane' in its description. Most mariners contented themselves with the terse descriptions common in their profession, although mention must be made of Lord Archibald Hamilton (HMS Eagle: Source S11) who, despairing of finding adequate words at his command, merely wrote in large script, 'a violent storme in the Downs' across his logbook page.

Debate surrounds the question of the origin of this storm. Defoe (1704) associated it with a hurricane. He states that "we are told they felt upon that [Florida and Virginia] an unusual Tempest a few days before the fatal 7th December." Regrettably, Defoe does not give his source. Neither does Brooks (1954) when he makes a similar claim. The exhaustive HURDAT data set (Source S24) begins only in 1851 while Ludlum's series (Ludlum 1963) goes back to the hurricanes encountered by Columbus on his later voyages but makes no mention of any such event in 1703 . However, many hurricanes do not make landfall and recurve around the Azores 'high' only to be re-invigorated as extra-tropical storms (Jones et al. 2003) and the possibility can by no means be excluded although December and January are not part of the normal North Atlantic hurricane season. 
Direct evidence is scarce but logbooks again provide the most persuasive, and that from HMS Centurion (Source S12), then moored in Nantucket $\left(41^{\circ} \mathrm{N} 70^{\circ} \mathrm{W}\right.$ ) is informative. The record indicates cold weather with northerly winds for much of the month. The logbook notes "deep snow falling day and night" (29 November), "great snow" (1st December) and "hard gales and very cold raw weather" (2 and 3 December). A diary kept by Manneseh Minor of Stonington in Connecticut also records "great snow" on 1st with further snow on 5th (Cary Mock, personal communication). This suggests the large-scale southward movement of polar air to meet tropical air. This cold weather continued until the early December and offers a suggestion of significant and persistent temperature contrasts across the region. It is therefore this contrast rather than any tropical origin that accounts for the "Great Storm" and the rising vigour of the several that preceded it earlier in the month.

The logbook of HMS Guernsey (Source S13) is also informative. This vessel crossed the Atlantic, leaving Cape Henry (Virginia) on 11th November. Her passage was stormy, with a series of strong and hard gales (force 9) with winds consistently from between south-west and north-west as one system after another rendered the crossing unpleasant, if relatively speedy. The storm that Defoe noted on 4th December is recorded to have passed the Guernsey on 2nd ("very stormy weather and much rain and lightning") in mid-Atlantic. The Great Storm overtook her on the afternoon of 6th December when she was some 120 miles off the Lizard. Both systems appear to have made rapid progress eastwards in keeping with the proposal that they were driven by strong jet streams.

\subsection{The winterstorm series "Hilaire-Prisca" (14th to 18th January 1739)}

This series of violent winter storms is not given much attention in the catalogue by Lamb and Frydendahl (1991) nor has it persisted in the cultural memory as did Defoe's storm of 1703. It has here been reconstructed from the primary sources, which therefore need to be discussed in detail.

A variety of individual sources on gales are available for France. Heads of households noted their accounting in family chronicles ("livres de raison") together with major events affecting their lives. Because such matters affected the family budget, climatic extremes including violent storms and soaring crop prices were often referred to Torres (2000). Though memorable personal and domestic events dominate most family chronicles, their abundance in sixteenth to eighteenth century France to some extent compensates this shortcoming. Occasionally, coastal parish registers contain brief notes such as "dreadful storm" if such events caused the death of seamen living in the community (Garnier 2000, 2004a). Ex Votos are pictorial analogues to such remarks in parish registers. An ex voto is a votive offering to a saint in fulfilment of a vow in the form of a small painting in memory of the blessing presenting fanciful or stereotyped representations of the disaster, the relief from which the vows were offered (Fig. 2).

The early consolidation of the monarchy in France from the fifteenth century led to the creation of a network of specialized administrative branches each of which prepared a body of institutional source documents. The most important were those of the "Intendancies of Police, Justice and Finance" who were placed at the head of each province under the reign of Louis XIV. These provincial records contain 
Fig. 2 Example of an Ex voto relating to a storm in 1770 (Source S25). No evidence is known for 1739

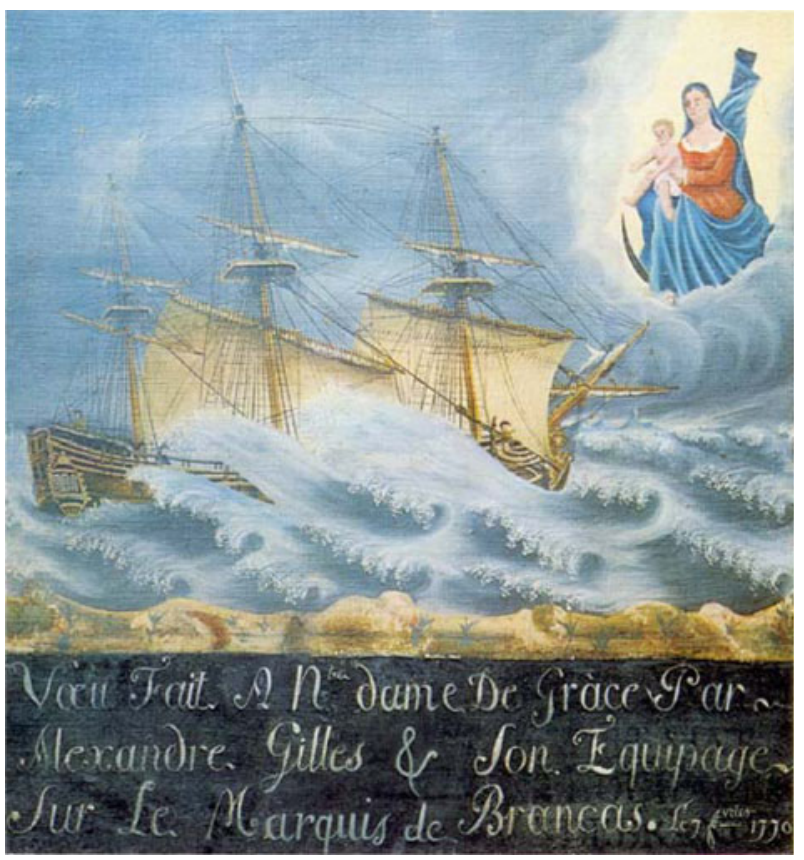

applications by disaster victims for tax relief. Most concern hailstorms, floods and frosts, but some report petitions in which inhabitants describe the damage caused by this and other storms (Favier 2002; Garnier 2007).

Windthrow inventories, the so called "chablis", are an institutional source documenting the effects of severe storms on forests in the French territory in terms of the number of trees destroyed. They were laid down according to the Great Ordinance on Water and Forests issued in 1669. The Ordinancy empowered the Royal Forestry administration to claim their part of all trees in the kingdom felled by humans or blown down by the wind (Garnier 2004a; Puyo 2005). Inventories give the location and the owner of the forest and detail the number, the species and the dimension of damaged trees: "The year 1739, January 14, me, Jean-Joseph Couli, guard of the Maîtrise of Rennes [..].Reports that 14 this month, between 8 hours and 9 hours of the morning, the wind being in the south produced a considerable storm with a great following thunder of a dreadful swirl, which twisted and broke a great number of trees in the forest of Saint-Aubin-des-Cormiers, in the cantons of Uzé and of the Chaine. The wind having continued all the day, the night of 19 to the 20 was followed of a considerable hurricane. Time being calmed a little, I was transported in the forest where I took note of what follows: One oak 4 feet in diameter, another 3 feet in diameter,another broken into two of 3 feet , another reversed of 3 feet [..., Jean-Joseph COULI" (Source S26). Sometimes the beginning and the duration of the storm and the principal wind direction were also reported. The inventories were verified by superior officers on the spot and Forest Officers were personally liable for trees missing from the inventory. Thus, it was in their own interest to carry out their tasks as diligently as possible. 
In Switzerland, on the other hand, most of the evidence comes from town and village chronicles, some of which provide detailed descriptions (Pfister 1999; Pfister et al. 2009; Krämer 2009). Valuable reports were written by Johann Bernhard von Effinger, a Bernese nobleman and agricultural reformer living in Wildegg (Canton Argovia) (Schwarz-Zanetti et al. 1997). The windstorms were an issue that preoccupied the nascent press exemplified by the wealth of correspondence by Isaak Vetter, who was the chronicler of the tiny town of Stein am Rhein (Pfister 1999).

From 14th to 24th January 1739 Western Europe was affected by a notable sequence of severe extratropical cyclones (see Fig. 6 for a survey). In Colmar (Alsace) "an eight-day storm" is mentioned (Garnier 2004b) while a source from the Swiss Mittelland reports strong winds mainly from the west over several days in succession (Pfister 1999). In order to provide an overview of storm activity during this month the events for which we have evidence are detailed in chronological order as follows: the first damage report came from the region of Rennes in Brittany and is dated January 14th, and timed for between 8 and $9 \mathrm{~h}$ in the morning. The same day the castle of Bayeux in Normandy was "largely knocked down to the ground" and the damage caused to the building was so great that it had to be rebuilt (Source S15). On the morning of 15th January, what was possibly a cold front was registered in the London area. According to a gazette a "most violent Storm of Thunder, Lightning, Wind, and Rain [...] continued for upwards of two Hours with such Impetuosity, that [...] great Numbers of Trees were blown down by the Roots [...]," (Source S1). At the Astronomical Observatory of Paris, Réaumur registered a thunderstorm the same morning accompanied by strong hail that lasted for three hours. The winds strengthened in the night of 15th to 16th January in Paris according to Jean-Dominique Maraldi (Source S16). On the morning of January 16th, day of Saint Marcellus, the gentryman Effinger in Wildegg noted the lowest air pressure level that he had ever witnessed. On the afternoon of the same day cyclone 'Marcellus' swept over the Swiss Mittelland uprooting trees and stripping roofs (Schwarz-Zanetti et al. 1997).

In the night of January 16th and 17th, the Abbey of Moiremont in Argonne was badly damaged (Boissiere 2005) and the Castle of Fontainebleau came near to total destruction. The damage was assessed at 13,797 French livres which correspond to more than thirty annual wages of a worker at that time (Belly 1996). In Wildegg strong warm winds persisted during January 17 th and the snow on the neighbouring hills (about $800 \mathrm{~m}$ a.s.l.) rapidly melted (Schwarz-Zanetti et al. 1997). At the same time in England, Cornwall suffered from heavy rain and stormy winds (Source S1), The following Sunday January 18th at 10 A.M. the "astronomers at the Observatoire de Paris registered a sudden drop in barometric pressure to $964 \mathrm{hPa}$. The pressure rose again to $995 \mathrm{hPa}$ at 3 P.M. to reach 1,016 $\mathrm{hPa}$ the next morning (Source S16). At 10 A.M. "Prisca" irrupted over Alsace and the Swiss Mittelland, where it ravaged until 5 P.M. being more persistent and violent than 'Marcellus' (Source S17). Central Switzerland experienced the strongest gusts between 12 A.M. and 3 P.M. The following day snowfall was abundant in the Swiss Mittelland and the Alps where avalanches did substantial harm (Pfister 1999). This sequence of events clearly indicates the passage of a deep cyclone, with a well-developed warm sector, then replaced by much colder, polar, air as the sytem moved eastwards.

A second phase of storm activity resumed from Saturday night 24th January 1739: The Caledonian Mercury reported a devastating storm in Scotland blowing 
west-by-south-west, and raging from the small hours of the morning causing substantial damage. At the same time, Irish sources confirm the damage in that region (Lamb and Frydendahl 1991).

Damage done by "Hilaire-Prisca" in the Forests is equally well-documented and the number of records available for France is so abundant that a selection had to be made. The following examples are sufficient to describe the violence of the gales. In the north of the country, the departmental archives relate the consequences of both "Marcellus" and "Prisca" for the forests. In the region of Fontainebleau (Îlede-France) $15,460 \mathrm{~m}^{3}$ of timber were blown down (Boissiere 2005). Likewise, the storms took a heavy toll on the Royal Forest of Hardt located near the Rhine. The inventory of the uprooted trees (Source S18) suggests that some 7,735 oaks of 1 to $1.50 \mathrm{~m}$ of diameter were blown down or broken "by the impetuous winter winds" without counting the other secondary species left out by the document (Dessert 1996). Likewise, tens of thousands of trees were blown down in the Swiss Mittelland: About 6,000 uprooted trees were lying on the ground in the region around Thun (Bernese Oberland). In the forests owned by the small town of Zofingen (Canton Aargovia) more than 15,000 trees were blown down. In Sirnach (Canton Thurgovia) a forest including old oak-trees was completely razed. Avalanche protection forests were razed in mountain regions such as Canton Glarus (Fromm 1981) and the Canton Nidwalden (Krämer 2009). In the small community of Beckenried the local priest registered the destruction of a thousand fruit-trees (Krämer 2009) (Fig. 3).

Some gusts were strong enough to lift people and to strand boats on local beaches. Amused observers described the repeated formation of waterspouts on Lake Zürich (Pfister 1999), as was also witnessed in the case of "Lothar" (WSL and BUWAL 2001). The burghers of Colmar reported in their family record books that "the strongest houses were destroyed by the winds". The same seems to have been the case in the German town near Vieux-Brisach (Source S19). In Catholic Lorraine, places of worship drew the greatest attention. In Saulxures "the violence and impetuousness of the winds has destroyed most of the chancel, nave and spire of their church" (Garnier 2004b). For several other places Swiss chroniclers mention the destruction of spires and the uncovering of church roofs. In a number of churches the bells were not rung from fear that ringers might be killed by falling spires or steeples. For the same reason many services were not held (Source S20). Information on mortality is, however, hard to come by and in Zürich all that is known is that a falling tree killed two people (Source S20). In the towns houses were stripped of their roofs and in Basel alone some 30,000 new tiles were needed (Bütler 2008). In Franche-Comté, the majority of farms in rural communities lost their roofs at the harshest time of year. The description made by the King's intendant is apocalyptic (Garnier 2004b). Likewise, most (straw covered) roofs in the Swiss countryside were blown away and barns and huts torn apart. Quite often, people fled outdoors in panic when their homes were shattered by the gales. The abundant snowfall succeeding "Prisca" marked the final blow for many households.

\subsection{Storm "Barbara" in Portugal (3rd to 6th Dec 1739)}

Extreme meteorological events-particularly severe droughts and heavy precipitation leading to material losses, hunger, disease, death and social disturbance were considered to be a punishment of God, due to Man's imperfections and 


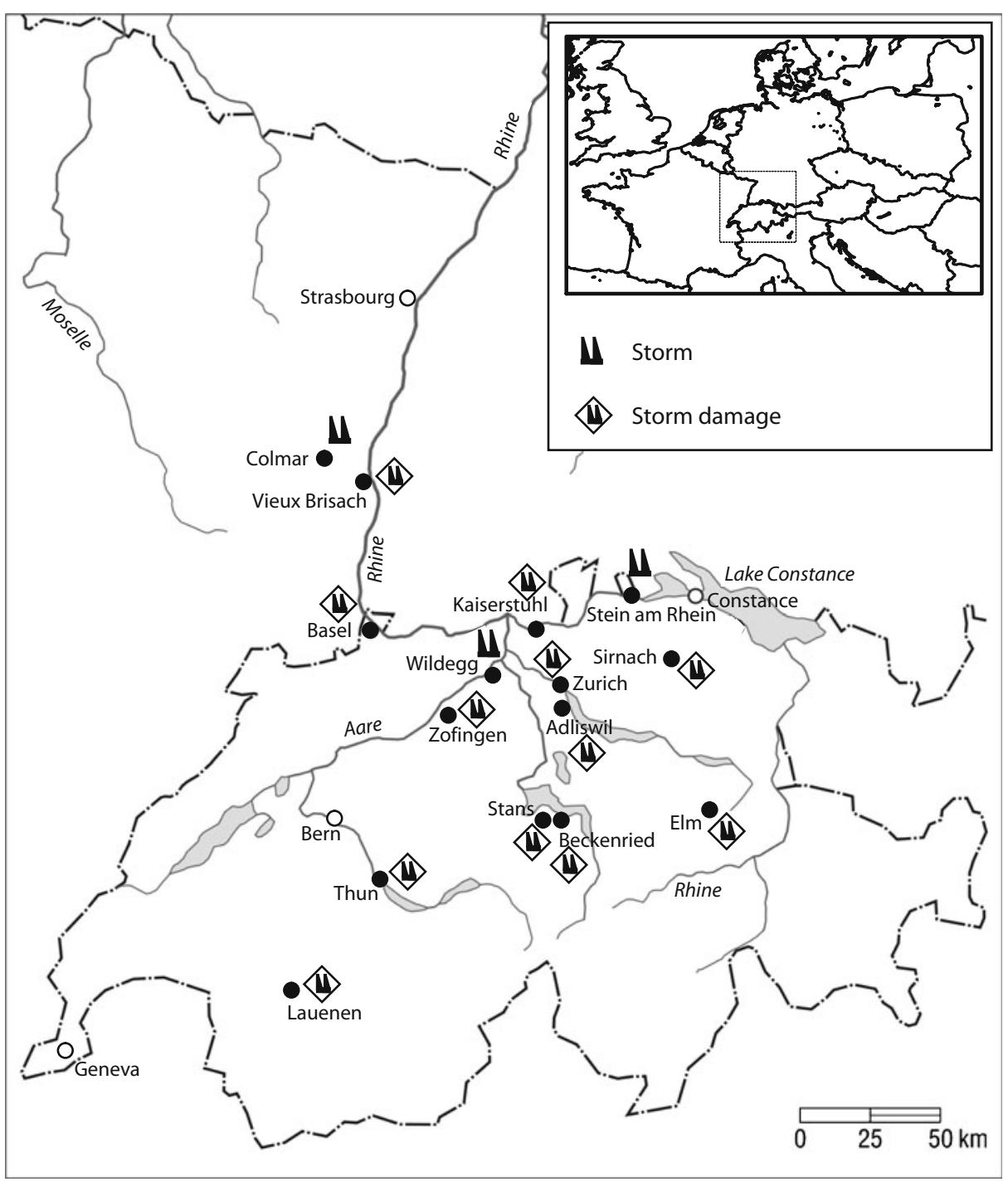

Fig. 3 Location of observations on "Hilaire-Prisca" in Alsace and in Switzerland

sins (Alcoforado et al. 2000; Taborda 2006). Such was the case in Portugal in December 1739, but ecclesiastical records are here supplemented by more poetic descriptions.

The winterstorm "Barbara" is mentioned in at least eleven sources. Individuallywritten sources (Sources S2, S3, S4, S5, S8, S9, S10 and S14), most of which were prepared by members of social and religious elites, the regular press (Sources S6 - Fig. 4- and S7) and the Minutes of the Chapter Edicts (Source S27) of Évora Cathedral all describe the storm and its consequences. But the most important individual printed sources are in the form of two poems (Sources S4, S5) and a publication of an astronomical prognosis (Source S10) that have proved to be 
key documents in the reconstruction of this extreme meteorological event. The commentator Martinho Lopes de Morais Alão provides evidence of the "Terrible Event of the Destruction of Oporto and its suburbs that happened in the terrible month of December 1739", in a 77-strophe poem that was published in Oporto in 1740 (Source S4). A 39-strophe poem "List of the damages unfortunately caused by an intense tempest in Coimbra from the 3rd to the 6th December of the present year of 1739" was written by the Jesuit José Coreia e Alvarenga (Source S5) and printed at the Royal College of the Arts of the Jesuits, right after the storm also in 1740.

The astronomical prognosis (Source S10) refers to astronomical and meteorological ephemerides and was edited in 1742 by Father Vitorino Joseph da Costa, one of the most important writers of 18th century ephemerous literature (Carolino 2003). The storm was mentioned in other manuscript sources including a two-volume contribution prepared by the Jesuit Luiz Montez Mattoso, a priest from Santarém, who in 1738 started a register of this city's memories of such events (Sources S8 and S9), and a manuscript from a cleric who wrote about Cuba (near Évora) (source S14). Finally, we have a copy of a document dated from 1739 (Source S2) and a recently printed (Fonseca 2001) anonymous manuscript (Source S3).

Fig. 4 Manuscript gazette from December 8th 1739, referring to the storm (Source S6)

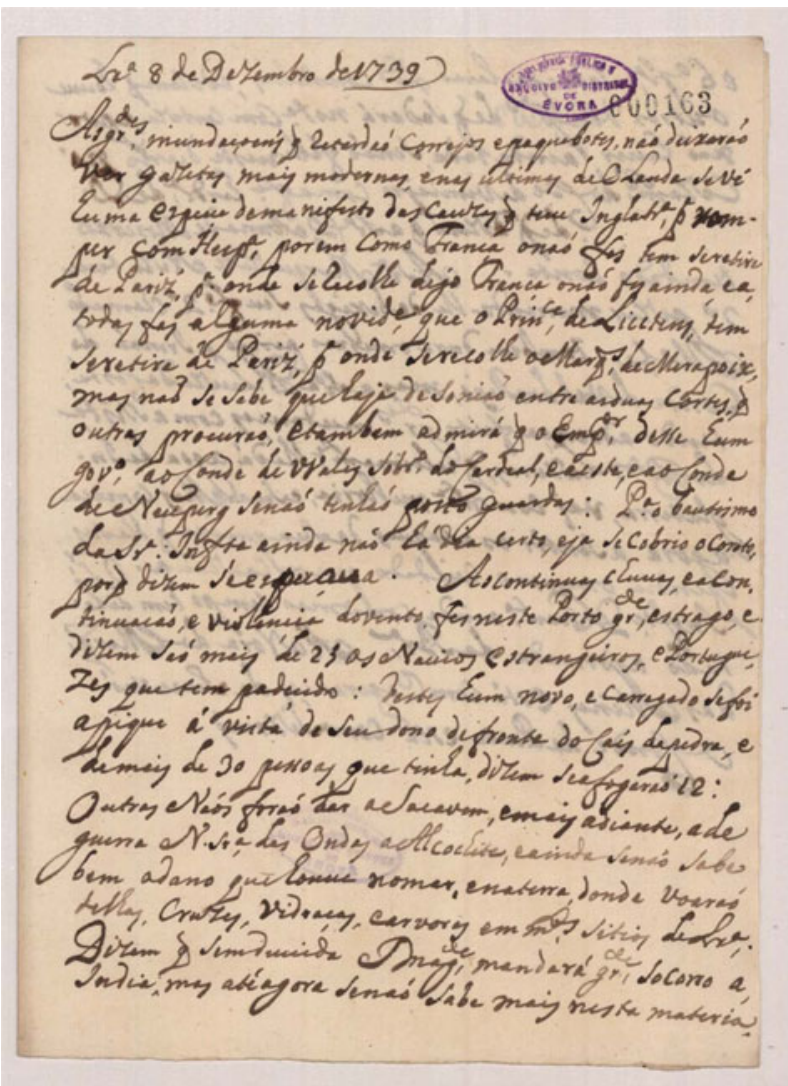


Evidence about "Barbara" was also found in the form of manuscript gazettes from Évora (Source S6) and in the "Gazeta de Lisboa" (Source S7), which was the official newspaper (Lisboa et al. 2002-2005).

Between the 3rd and the 6th December 1739, the weather of Portugal was characterised by violent winds and heavy rainfall. The descriptions of poor weather and its consequences were widespread and come from many parts of the country (Fig. 5). Costa (1742, Source S10) writes that "when the new moon was beginning to grow, on 3rd December 1739, a southern wind was blowing, arrogant and violent [...] and gave rise to a horrible storm [...] that caused people to forget the older ones" (p. 1). In relation to wind force, expressions such as "horrible hurricane" and "disastrous storm" (Source S14) were commonly used. In addition to the violence of the winds, there was heavy rainfall following an already wet autumn (Source S6).

"Barbara" caused great damage in Oporto, as Alão describes in his poem (Source S4). He specifies the date of the beginning of the flood (3rd December, strophe XIII), and marks the 4th and 5th as the dates when the most torrential rain and flooding occurred (strophe XV) and the 6th as the day when the storm came to an end. In the first strophes, general indications are given about the violence and the clamour of the wind and its consequences. Only later in the poem (strophes XIV, XV) is rainfall mentioned, together with thunder and hail: the author writes about a new "deluge" and a tempest of rain and wind (strophe XVI). In his description of the floods of the Douro River (Fig. 5) Alão gives a detailed geographical description of the damage. In Peso da Régua, in the area of the port wine vineyard, destruction was widespread. In Oporto the port wine storehouses on the Douro suffered massive destruction and were rendered a "universal ruin". In the western areas of Oporto people escaped their houses through windows and roofs as the level of the Douro rose.

After strophe XLV the destruction of churches and public buildings of Oporto is described, from which the limits of the flood can be assessed. Storm-force winds blew first from the south and Alão indicates that the storm lessened when the wind direction backed to the north. Thanksgiving ceremonies are described at the end of the poem (Source S4).

Further south in Coimbra (Fig. 5), the storm is described in the poem by Alvarenga (Source S5). Unlike Alão's poem there are few descriptions of places and the sequences of events but the dates (3-6 December 1739) are included in the title. Heavy rainfall, hail, thunderstorm, lightning and particularly strong winds are referred to several times as well as very high floods of the Mondego river causing loss of human lives and enormous material damages (including the destruction of the bridge over the rivcr) turning the city into a landscape of ruins. Alvarenga emphasises the amplitude of the floods stating that the streets were transformed into rivers and the houses into islands, he continues:

More and more the violent winds

Are causing universal ruins

From side to side compelled

Devastating buildings and houses

In Santarém (Fig. 5) and in surrounding areas intense rain began on December 2nd 1739 and on the 3rd the level of the Tagus continued to rise until Friday 4th. The flood was cited as the highest of the preceding 40 years (Source S9). The author 


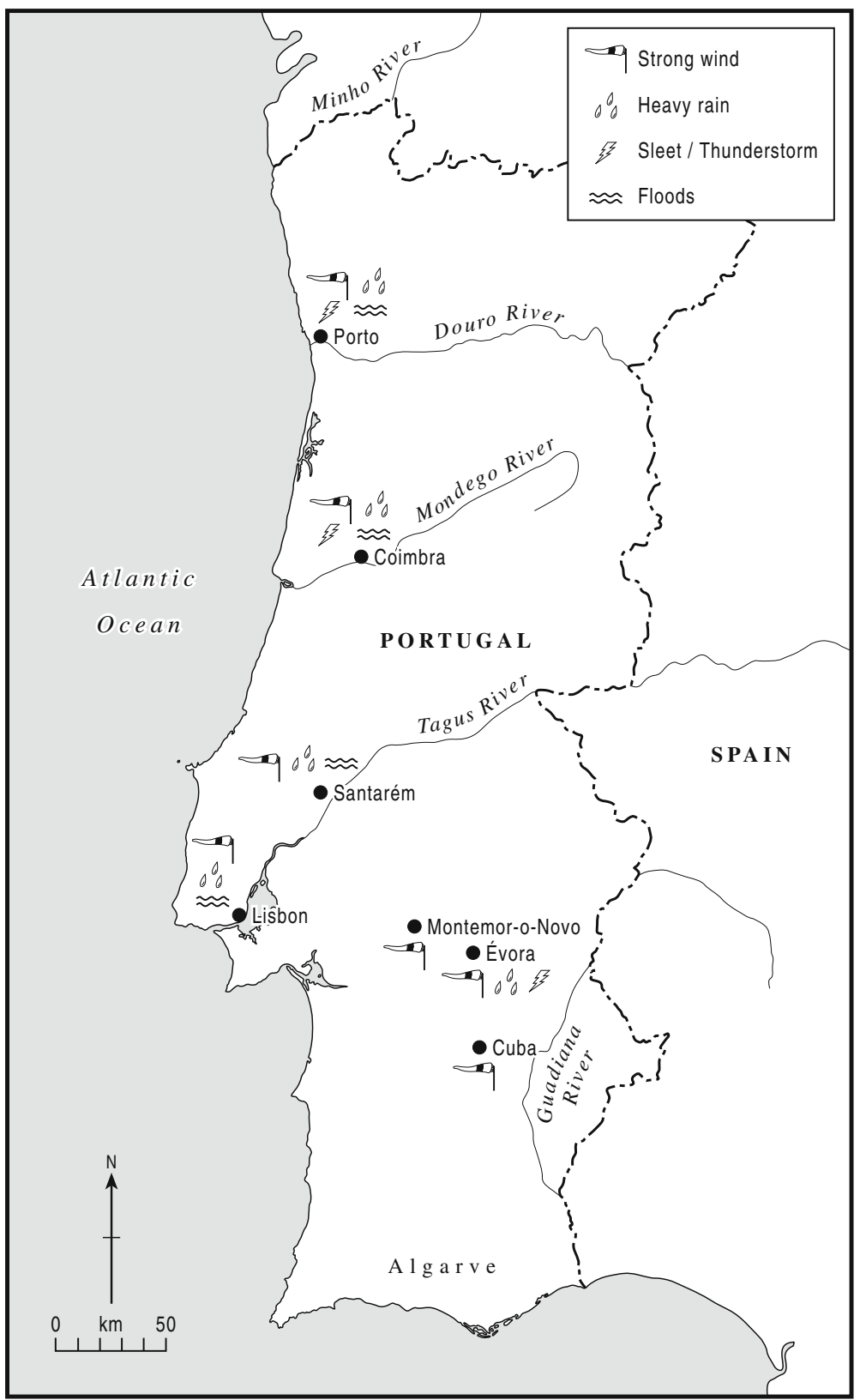

Fig. 5 Map of Portugal representing the observations during "Barbara" (adapted from Taborda 2006)

had already written about the very wet years of 1735 and 1736, (Source S8) but he describes this episode as worse than any he could remember. November 1739 had been a very rainy month and there is a reference to a "terrible day" (with no date 
indication) when it rained ceaselessly for $15 \mathrm{~h}$ leading to the first autumn floods of the Tagus. This intense rain doubtless added to the December floods, as the soils were already saturated (Source S6).

For Lisbon there also exist detailed accounts of the consequences of the heavy rain, and of the strong wind that threw people to the ground, unroofed houses and unrooted trees (Source S10). There was so much driftwood available that city inhabitants were able to collect wood for their personal needs for long afterwards (Fonseca 2001). There are also references to damage "to more than 23 Portuguese and foreign vessels", that were anchored in the Tagus estuary (Source S6), at least one was sunk standing on the anchorage and 12 were swamped (Sources S6, S7, S10; Fonseca 2001). The southerly winds were so violent that warships anchored in the Tagus drifted upstream several kilometres (Source S7).

These observations on wind direction and strength are confirmed in the logbooks of two English vessels HMS Seaford (ADM51/4336/III) and HMS Adventure (ADM51/12/XII) anchoring in Lisbon. On 3rd December a storm with heavy rain is referred to between 1 and $2 \mathrm{pm}$. The pilot writes of "hard gales" (Beaufort 9 and 10) on the 4th and "fresh gales" (Beaufort 7 and 8) on the next day. During "the latter part" of the day the weather is reported as cloudy with "small showers" of rain. The wind had backed to northwest and north, which agrees with Alão's statement (Source S4) for Oporto. Northeasterly winds and calms with "fair weather" are reported on 7 th December suggesting the reappearance of anticyclonic conditions.

Further south, in Évora (Fig. 5) the 1st of December procession in honour of the King John IV was confined within the cathedral and the cloister but the most intense "water storm" occurred on 4th and 5th December, accompanied by thunder on the 4th-St Barbara's day - this saint being ironically the "protector" from thunder (Source S3 and Fonseca 2001)!

\subsection{Discussion}

Considering the almost identical geographic range and the similar meteorological context of the "Great Storm" and "Hilaire-Prisca" it is appropriate to discuss these two events collectively whereas "Barbara" needs to be dealt with separately.

Lamb and Frydendahl (1991) estimate the surface wind speeds of the "Great Storm" in England to have been up to 80 or 90 knots (approximately 140 to $155 \mathrm{~km} / \mathrm{h}$ ) and this places it firmly in the 'hurricane force' category of the Beaufort-Scale [in fact a scale 1 hurricane]. Considering its impacts in the Low Countries, Démarée and Muir-Wood (2009) place it among the most violent storms of the last 500 years and compare it to "Lothar" and "Martin" (1999). However, in Lamb and Frydendahl's (1991) catalogue of such events in the North Sea region the "Great Storm" ranks only fifth in their series scoring 9,000 on their 'severity index'. Just 9 years earlier a storm in November 1694 scored 10,000; the storms of 4th February 1825 and of 10th-12th December 1792 score 12,000, and that of 15/16th October 1987, 20,000.

The month of January 1739 was however characterized by a long series of violent storms over the North Atlantic Ocean and Europe. The entire sequence lasted from January 14th to 24th i.e. approximately 240 hours. Lamb and Frydendahl (1991) only mention its final "Scottish" phase (24th January) and did not include it in the list of long lasting storms. However, considering the "continental" phase alone of "HilairePrisca”, the gales lasted for about 100 h. No storm in Lamb and Frydendahl's (1991) 
list for the British Isles area rivals the latter for duration. Individual meteorological factors that favour the development of strong extratropical cyclones over the eastern Atlantic Ocean and that steer these powerful storms to Central Europe are wellknown (see Ulbrich et al. 2001; Wernli et al. 2002; Fink et al. 2009; Pinto et al. 2009) these being an enhanced north-south tropospheric temperature contrast associated with a very strong upper-tropospheric jet stream directed towards Europe, a welldeveloped upper-level outflow at the left exit region of the jet stream, sometimes augmented by the co-located right entrance region of a downstream second jet streak, upper-level dry air intrusions overriding existing frontal structures, and the inclusion of anomalously warm and humid air in the warm sector of the cyclone. The extreme duration of the storm sequence was probably favoured by a persistent and strong temperature gradient over the North Atlantic Ocean and Europe.

Figure 6 confirms this interpretation and shows the reconstructed SLP field for January 1739 (Luterbacher et al. 2002) with a well developed Azores high and deep Icelandic low, giving a positive NAO index. The winterstorms "Vivian" (1990) and "Lothar" (1999), on the other hand, are not revealed in the monthly sea level pressure distribution. The difference between the "Great Storm" and "HilairePrisca" therefore seems to be less related to the severity of the events than to their duration.

Storm "Barbara" remains the greatest event of this kind in northern and central Portugal. The storm there appears to have been worse than in the south (Algarve) with winds backing from south to north. These facts suggest a westerly circulation,

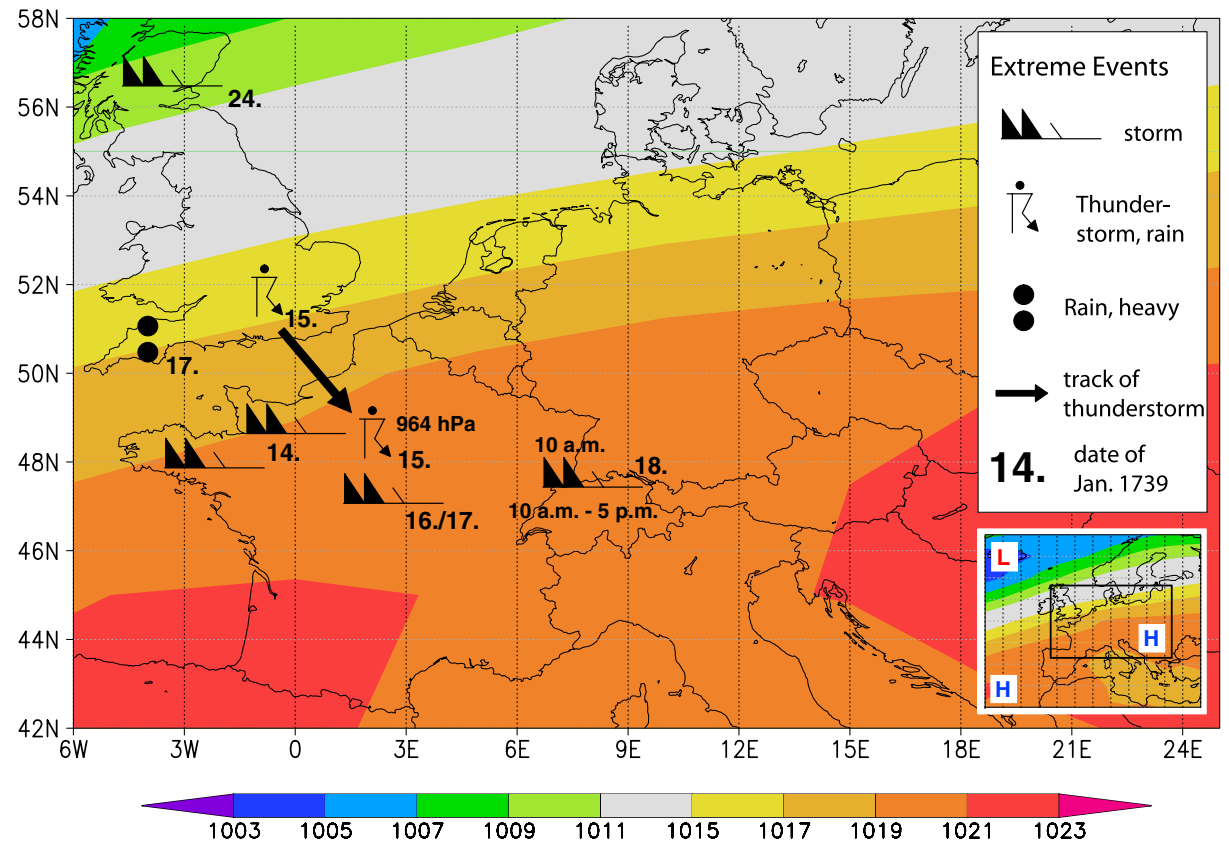

Fig. 6 Reconstructed sea level pressure distribution (in $\mathrm{hPa}$ ) for January 1739 (Luterbacher et al. 2002) with symbols indicating observed cyclone and associated position with lowest core pressure, thunderstorms and heavy rain 
with successive passages of frontal surfaces and associated bouts of rain and wind with cyclonic centres to the immediate north. The synoptic situation on the 25th February 1978 can be considered as an analogue case of the 1739 storm (Daveau et al. 1978), with a surface low pressure centre westwards from the British Isles and a strong barometric gradient towards the south. Wind speeds in 1978 exceeded $90 \mathrm{~km} / \mathrm{h}$ and the waves attained $10 \mathrm{~m}$ in height. In 1739, the wind speed reported by the British mariners attained what today would be described as 10 Beaufort (between 88 and $102 \mathrm{~km} / \mathrm{h}$ ), and the damage described in the sources is commensurate with such speeds.

\section{Cultures of coping and memory-keeping}

When Borst (1981) published an article on the disastrous Villach earthquake in 1348 he pointed to the different perception of such events in the Far East and in Europe. In China and Japan preparatory works to ready the population against a persistent danger instead of for an isolated shock were commonplace. He then goes on to suggest that in Europe, disasters are not recognized as a "lasting experience of society and history", because this recognition would "deeply contradict the modern European approach to life which isolates catastrophes in the present and eliminates them from the past, because they should not determine the future" (Mauelshagen 2009). But can the loss of memory in the case of the "Hilaire-Prisca" windstorm series really be explained in this philosophical context? Reference to the "Great Storm" and to "Barbara", of which the cultural memory was kept alive may be helpful in resolving this issue. This objective necessarily involves the interpretation of the events and the strategies of coping, as far as they are known and evidenced by the contemporary sources.

\subsection{Memories of the 'Great Storm'}

The Great Storm struck England at a critical time in its political history and in the development of European thought. It stands on the divide between Age of Enlightenment and the post-Medieval view of the spiritually-controlled world in which mankind lived. Whilst the upper classes were adopting a more rationalist view of the world, the working population clung to their traditional beliefs and superstitions. Seminal reflections on the nature of wind and storms had already been published by Bohun (1671) and Dampier (1699). So how was the storm understood by those who witnessed its most violent expressions? At a time when many scientists were also ordained ministers, it is not surprising that a neo-apocalyptic interpretation was put on the event. Defoe's opening sections eloquently attributes the general nature of weather thus:

"Nature plainly refers us beyond her Self, to the Mighty Hand of Infinite Powers, the Author of Nature, and Original of all Causes. Among these Arcana of the Sovereign Oeconomy, the Winds are laid as far back as any. Those Ancient Men of Genius who rifled Nature by the Torch-Light of Reason even to her very Nudities, have been run aground in this unknown Channel; the Wind has blown out the Candle of Reason, and left them all in the Dark." (p. 12) 
There is little doubt that for the majority of people, the event was seen as a visitation of the Almighty's displeasure. More eloquent of a sense of biblical judgement were the reflections of the mariner Edward Barlow (Lubbock 1934), whose first-hand account includes the following:

"I pray god we may all repent, for doubtless that was a warning of God's anger against us, for a worse generation can scarce be in all wickedness."

A less well-known example of the intellectually transitional nature of the age is offered by an anonymous diary kept in 1703 in Worcesteshire (Golinski 2001). The writer moves towards a rational view of the weather but the following quotation is laced still with a more religious interpretation of the world: "I verily am of this creed, as Meteorology must be establisht \& explained by a sound Geology or penetration into ye mundus subterraneus, what we call ye heavens is but ye excrement \& refuse of what we name Hell." His account of the storm is no less a mixture of attempts to engage in objective description whilst feeling obliged to acknowledge a more spiritual element at work: "A most dreadful night for violence of [wind] \& rage of it most tremendous \& inexpressible.....as if the [the] whole mass of air were putt into a ferment of convulsions \& haunted with Furies, or Exasperated by Aeriall demons \& agitated or spurd with all ye Aeolian Powers."

The economic consequences were more immediate: the price of tiles, bricks and building materials, as did labour costs, rose sharply in the weeks after the storm-Defoe noted that the price for plain tiles rose from 21 shillings (£1.10) to $£ 6$ per thousand-but with no lasting consequence detectable in the economy. Food supplies were equally limited and the 400 or so post mills that were lost were soon replaced. Less easy to replace were the mariners of the merchant and Royal Navy service. It is estimated a significant proportion (between $5 \%$ and $20 \%$ depending upon the source) of the Royal Navy's compliment of 40,000 mariners were lost that night. Trevelyan (1930) describes the possible role of the event in history thus: "English naval supremacy was nearly broken and the war lost by the sudden, brief and unprovoked intervention of a neutral power. The Great Storm, without rival in the recorded history of our islands." Nevertheless within a year a substantial Anglo-British fleet under Admiral George Rooke was able to invest and capture Gibraltar. The immediate economic consequences went beyond the shores of the British Isles. To cite but one example, the need to replace not only crews but also ships took British agents to their usual purchasing grounds of the Baltic region for timber for masts and yards. Queen Anne's agent approached the Swedish Court of Charles XII with requests for substantial bodies of timber (Source S21) the quantities of which were large enough to raise concerns that elevated prices might encourage enterprising, if illegal, cutting to take wood from the Royal Forests. No less than 400 substantial bodies of timber were requested, presumably for masts, the size (probably circumference) sought being 19-20 palms (152-180 cm; a Swedish palm is 8-9 cm). However, setting aside the purely economic consequences of the storm, which were catastrophic in themselves, it was this loss of life and shipping, much of it within sight of a horrified coastal population that left the most indelible mark on the collective memory. On the continent, where the "Great Storm" claimed fewer victims and perhaps caused less damage, it fell soon into oblivion, in contrast to the "Christmas [Storm] Flood" of 1717 (Démarée and Muir-Wood 2009). Two years earlier a storm surge caused large scale flooding in the southwest part of The Netherlands and 
Flanders and storm events causing flooding became part of the collective memory, single storm events in this area, it seems, did not.

\subsection{The lost memory of "Hilaire-Prisca"}

In France the response to the storms reflects the tendency to centralization through a powerful and specialized administration. Among the many bureaucracies, the "Water and Forests" Administration have bequeathed a veritable goldmine of records of windthrow inventories (see Section 2). A second French characteristic is the early abandonment of the topos of Ira Dei, i.e. the wrath of God, in favour of a rationalist world view. This change applies not only to administrative data but also to private and religious sources. Even the French priests who witnessed the fall of their steeples describe the events with cool objectivity providing the date, the time of the event and describing the impacts without any religious reference. The same attitude is found in the diaries of burghers in places as far apart as Normandy, Paris and Alsace. Though many of them may have been good Catholics, they were thinking in the spirit of the Enlightenment. The few references to religion are all local and populist initiatives as demonstrated by the community of the valley of Munster in Alsace, whose parish register written in German includes the annual forty hours-prayer after the storm of January 1739. This otherwise mainly secular response to the disaster of "HilairePrisca" is not vastly different to the mentalities prevailing more recently on the eve of the new millennium, when "Lothar" and "Martin" struck Western Europe.

Elsewhere in Europe similar trends were detected. The old Swiss Confederation was split up into a patchwork of small territories that were diverse in terms of geography, economy, law, language, religion and culture. Here too biblical worldviews were being eroded by new scientific practices and discoveries at the time of "Hilaire-Prisca", but without being fundamentally challenged. Johann Jakob Scheuchzer, to take the example of the most prominent early eighteenth century Swiss scientist, found in "Noah's Flood" the answer to the puzzling question of why fossil shells and mussels were found even in the highest Swiss mountains. In his chronicle of catastrophes in Switzerland written in 1733 he wrote about natural causes but not about God's wrath (Kempe 2003). On the other hand, parts of the elite and of the clergy still clung to the biblical dogma. More than a month after the storms, the protestant cantons scheduled a half-day of penitence during which sermons were held and shops remained closed (Fig. 7). But some areas were less enlightened. The head of the church of the Canton Zürich, Conrad Wirz, ascribed the storms to the bigotry of the churchgoers. It was not by chance, he declared, that the thrust of the second, stronger storm occurred precisely at the time of the service on Sunday morning and this coincidence was understood as God's warning that it was not sufficient to listen to His word on Sunday and to live in sin during the week. He explicitly excluded any other scientific reasons (Source S20). Extreme events were usually interpreted against the background of corresponding scriptures. Windstorms are not, however, part of the 'apocalyptic troika' of war, plague and famine (Huhn 1987) and, not surprisingly, Wirz could only find a few scriptures for his sermon (Krämer 2009). In the rural catholic Canton Nidwalden the "weekly council" required a procession to the sacred sites and it had the monstrance, the vessel used in the Roman Catholic Church to display the consecrated Eucharistic Host, exposed and dancing was prohibited for the impending carnival (Krämer 2009). 
Fig. 7 Memorandum published by the Swiss Protestant Cantons in February 1739: (Source S20)

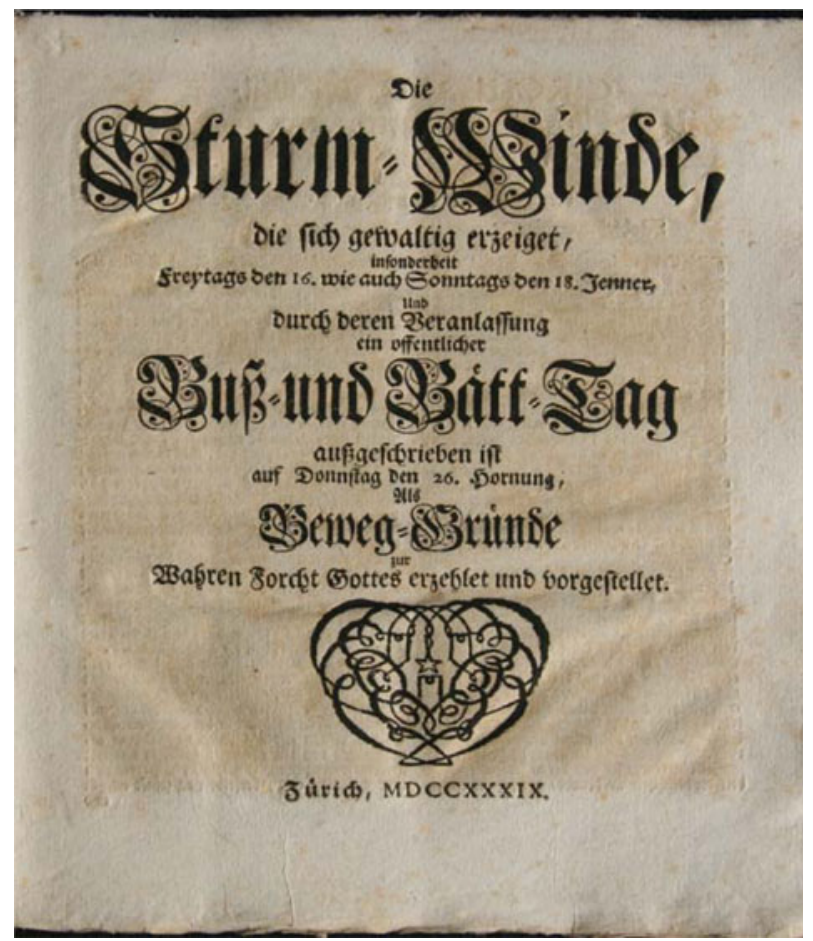

Allowing for the difference in rituals and religious tradition the representatives of both creeds responded practically in similar ways to the disaster caused by "Marcellus" and "Prisca". Searches of the state archives of the Cantons Basel, Zürich and Nidwalden revealed documents referring to supplications brought forward by poor people whose houses and livelihoods were ruined by Prisca". In Canton Nidwalden, the council provided financial assistance only to very poor people whose houses were wrecked (Krämer 2009). While in the Canton Zürich the council did not allow the baillifs to pay any subsidies or concede "begging licences" and in the Canton Basel the members of the Little Council granted timber from windfalls as an emergency assistance to poor people whose houses were damaged (Bütler 2008).

Though the storms were an issue in the nascent press, they seem not to have impressed the civic authorities. The outstanding severity of the event is mentioned only once in the lengthy protocols of the Basel Council (Bütler 2008). Likewise, 'official' chroniclers did not sustain the memory of the events in the past (e.g. Riggenbach 1891).

\subsection{The case of "Barbara"}

In the case of Portugal, the lasting memory of "Barbara" mainly seems to hinge on the two poems written by Alvarenga (Source S5) and Alão (1740) describing the event and its consequences. In the 1730s the ideas of the Enlightenment were beginning to penetrate the Catholic world view of southern Europe. New concepts of weather and climate had a prominent place in the enlightened perceptions 
disseminated in Portugal by an active network in which editors and typographies had a predominant place (Belo 2004). Obviously the learned members of the Jesuit community were aware of the importance of contrasting the new understanding of weather with the traditional biblical interpretation. Characteristically both poems were approved by censorship bodies active at that time.

\subsection{Discussion}

With regard to windspeed and its biophysical impact upon the forests, the built environment and infrastructure "The Great Storm", "Barbara" and "Hilaire-Prisca" display substantial correspondences. England and the Low Countries, Portugal, France and Switzerland were all ravaged by storms of hurricane-force at times, each causing destruction that was almost warlike in its intensity and consequences. Major differences are obvious however in the ways the disaster was inscribed in the cultural memory.

The "Great Storm" in England is one of the few extreme events that made its way into the mainstream of political history prior to the 1980s through the appalling but temporary loss of naval power both in terms of timber and crew at a critical moment during the War of Spanish Succession. It also became immortalised inworld literature through Daniel Defoe's description in his novel 'Robinson Crusoe' (1719). On the continent, however, where the number of casualities seems to have prompted less concern, and the memory of the event soon faded.

In the case of Portugal, which was a bastion of Catholic Orthodoxy, "Barbara" and its consequences were described in two poems by Alão and Alvarenga written in the Catholic baroque culture that considered weather extremes as responses from God to the sins of mankind. We may assume that they were instrumental in keeping the cultural memory of "Barbara".

The French case is also ambiguous. Forest damage was emphasized in 1739 because in contrast to the English navy, the French fleet was able to meet its timber demand from national sources but, unexpectedly, the impact of "Hilaire-Prisca" deprived the arsenals of Le Havre and Cherbourg, Marseille and Toulon of their usual quantities of prime forest timber. The large Royal Forests in Normandy and in the Vosges suffered the full brunt of the hurricane-force storms in terms of the tens of thousands of broken trees. Thus, after the storm of January 1739, a new form of vulnerability, the fear of being invaded by the Royal Navy, emerged in France. This aggravating factor for the country needs to be considered in the longer term. In contrast to England, where coal was already mined in substantial quantities, the French industries still depended on charcoal and fuel wood (Dessert 1996). Was the memory of "Hilaire-Prisca" suppressed in order to allay French public concerns surrounding an awakened sense of the English naval threat?

The response of the Swiss cantons stands in contrast to those in England and France. The reluctance of their authorities to enlist "Prisca" in the known record of extreme events seems to be rooted in the severity and ubiquity of the damage and in the inability of any assistance to be provided to the victims except to the very poorest. Indeed, the funding for such massive country-wide losses would have exceeded the capabilities of even modern insurance structures without the backing by a world-wide system of re-insurance, not to mention the challenge to the public resources of a small republic. The fact that the memory of river floods and rockfalls, where large tracts of 
the country remained unaffected and required fewer costly responses, was well kept (Pfister 2002; Favier 2007) would support with this interpretation. Bos et al. (2005) demonstrated from two cases in the 1990s - the Amsterdam air-crash of 1992 and the Estonia Ferry Accident (1994) — that the extent and nature of disaster remembrance is not solely a question of physical characteristics such as the number of casualties, nor of the degree of social disturbance they cause at the time of their occurrence. Instead, it should be viewed as a product of a political encounter between grassroots memory and the elite-level, suggesting a political "processing" of disasters. In the "Estonia" case the victims where overwhelmingly white, middle-classs, wellintegrated citizens who could make their voices heard in the political arena. The Amsterdam air-crash however hit a poor, multi-racial socially marginal community, state support was absent and for this reason the memory of it soon passed from the collective consciousness. Some similarities with the case of "Hilaire-Prisca" are obvious. The tendency to wipe out the collective memory of the events may have been rooted at first in the huge difference in social vulnerability between the urban elites residing in solid houses and the rural poor living in thin dwellings. More importantly, however, the helplessness and paralysis of the authorities in the face of the countrywide destructions needs to be stressed. Their quasi-passive attitude was in clear contradiction of the official doctrine of paternalism. Rulers made a point of caring for their subjects with ostentatious gestures such by promulgating mandates against speculators or opening public grain magazines in situations of dearth. The actions of the authorities, even if they were merely of a symbolic nature, were inscribed into the public memory to glorify the paternalist regimes (Huhn 1987). Obviously, "Hilaire-Prisca" did not fit into the known paradigm and the authorities probably perceived it as a failure of their policies and chose not to sustain its memory.

\section{Conclusion}

The scientific community is relatively well-served by data on past temperatures. However, as this paper demonstrates, there are significant gaps in our knowledge of the chronology of European storms, even considering extreme events occurring in the recent past and affecting core areas such as the Parisian basin, the Rhineland and the Swiss Mittelland. In consequence, a storm of the severity of "Lothar" could not be anticipated and the shock of the event was so much greater as it paralysed the power supply, this being the Achilles heel of consumer societies. At the same time, such shortcomings in the cultural memory also prevent an appropriate assessment of present and future storm risks that to some extent hinges on the knowledge of past events. Economists (Freeman et al. 2002; Stern 2006; Hallegatte et al. 2007) stress that we need to explore disasters of the past in order to obtain real data and information instead of relying on model results. History is always present-day history in the sense that it weds the wealth of past experience to the issues that are relevant for the respective present. In this context, documentary data yield a unique wealth of detailed information which is frequently overlooked by scientists and engineers.

The three storms occurred in the first half of the eighteenth century, when the traditional 'Acts of God model' of disaster was challenged by a new understanding of disaster arising from the Enlightenment wherein causality lay within 'nature' (Juneja and Mauelshagen 2007). There seems to have been such debates on causality 
of disasters in protestant England after the "Great Storm". To conclude from the sermon of deacon Wirz the protestant orthodoxy in Zürich was in a position of defense after "Hilaire-Prisca", whereas in France the 'Acts of God' model was already fading at that time. In Catholic Portugal storm "Barbara" was utilized to invigorate the traditional dogma through the publication of the two poems without, however, explicitly referring to the new ideas. Likewise, in the Catholic Swiss cantons, enlightened models of causality are not mentioned in any document. Finally, this paper challenges the assumption, that the place of an extreme event in the cultural memory is necessarily related to its severity in terms of casualties and materials losses. At least in respect of severe windstorms there was a tendency to disregard such events in both Catholic and Protestant milieus, unless they claimed a large number of victims. This attitude was perhaps rooted in the inability of authorities to meet their traditional paternalist roles to assist the victims in situations where the damage was widespread. This fading out of the past led to the paradoxical consequence, that the authorities of the modern democratic French state were just as much surprised by "Lothar" as the rulers of the kingdom of Louis XV had been by "Hilaire-Prisca".

Acknowledgements Christian Pfister is supported by the Oeschger Center for Climatic Change Research (OCCR) at the University of Bern, the National Centre of Competence in Research (NCCR) Climate and the EU Sixth Framework Program Integrated Project 'Millennium' (017008-2). Jürg Luterbacher acknowledges support from the EU-7th Framework program ACQWA (www.acqwa.ch) under Contract \#212250. Emmanuel Garnier's research is supported by the French Forestry Administration. The "Laboratoire des Sciences du Climat et de l'Environnement (CEACNRS)" and the Centre de Recherche d'Histoire Quantitative (UMR CNRS) at the University of Caen. Dennis Wheeler acknowledges the support of the EC through the FW6 078008-2 project Millennium. Thanks also go to Lotta Leijonhufvud (University of Stockholm) for drawing attention to the Swedish records of timber request made by English agents in 1704. Daniel Krämer compiled the bibliography and references. Chantal Camenisch translated an article in Dutch. Franz G. Kuglitsch (Institute of Geography, University of Bern) prepared Figs. 3 and 7. Two anonymous reviewers are credited for their elaborateness and their constructive critique.

\section{References}

\section{Manuscript and internet sources}

S1 http://www.pastpresented.info/cour-storms1739.htm (January 1739, storm, Jun 18 2008)

S2 Jdades tresladadas de hum papel ja velho para este novo, Cunha Rivara, cod. cxxxi/1-6, no. 3; fl. 5. Évora Public Library

S3 Triste e alegre cidade de Évora: testemunho de um anónimo do século XVIII/estudo e transcrição T. Fonseca, 2001. Evora, CM

S4 Alão ML de M (1740) Sucesso lamentavel da destruiçam do Porto, e seus suburbios acontecido no fatal mez de Dezembro de 1739 [...], Porto, anno de 1740 [poem], 27p

S5 Alvarenga MJC (1740) Relação dos estragos, que desde o dia 3. de Dezembro athe 6 do mesmo mez do prezente anno de 1739 infelizmente cauzou nesta cidade de Coimbra huma sempre memoranda tempestade [...]. Coimbra, Real Collegio das Artes da Companhia de Jesus, 15p

S6 Gazetas manuscritas da Biblioteca Pública de Évora Dezembro 1739. Cód. CIV/1-8 d. Évora Public Library

S7 Gazeta de Lisboa, 26 de Abril de 1725; 10 de Dezembro de 1739

S8 Mattozo Pe LM (1738) Memorias para a Historia Scalabitana, Chronologica, secular, e Ecclesiastica [...] Comecou esta obra a 13 de Fevereyro de 1738. em q.e sahiu o Sanctissimo Milagre. Tom.I. Santarém Anno de 1738. Reservados, cod. CIII/2-5 Rel. 2. Évora Public Library 
S9 Mattozo Pe LM (1738) Memorias recomendadas a estampa [...] principio de Janeiro de 1738 conthem alguns sucessos dos annos antecedentes por não sepultá-los os de todo a esquecimento, Santarém MDCCXXXVIII [1738]-Cod. CIV1-25: Fl 3v; Fl. 4 [1739]. Évora Public Library

S10 Costa VJ da (1742) Prognostico novo do cometa e mais impresoens metereologicas do anno 1737 até o presente de 1742: crisis astrológico, filosófico, theologico, moral e politica, Lisboa, Officina Miguel Rodrigues, $\mathrm{p} 28$

S11 Captain's logbook, HMS Eagle, National Maritime Museum, Greenich (UK) ADM/L/E.4

S12 Captain's logbook, HMS Centurion, National Archives, Kew (UK)

S13 Lieutenant's logbook, HMS Guernsey, National Maritime Mueum, Greenwich, UK ADM/ L/G.174

S14 Oliveira FJ de (1742) Memoria Histórica do Lugar de Cuba. Cod.104. Cuba Municipal Library

S15 Archives départementales du Calvados, C 1081

S16 Mémoires de l'Académie des Sciences. 1739

S17 Ms Johann Bernhard Effinger. Schlossarchiv Wildegg, AW 27, AW 25/79 und AW 79a

S18 Archives départementales du Haut-Rhin, 2 B 33

S19 Archives départementales du Haut Rhin 6 C 58

S20 Die Sturm-Winde die sich gewaltig ereignet [...] Zürich 1739. Zentralbibliothek Zürich, Msc S 618

S21 Amiralitetskollegii skrivelser till Kongl. Maj:t 1704, Vol 23. Swedish National Archives, Stockholm

S22 "Le Monde", Jan 7th, 2000

S23 "Le Monde", Dec 28th 1999

S24 http://www.aoml.noaa.gov/hrd/hurdat/index.html. Accessed 6 June 2008

S25 Cathedral Notre-Dame de Grâce, Honfleur, France

S26 Archives départementales d'Ile-et-Vilaine France)

S27 Codices Eborensis Capituli 14-IV to 14-VII. Évora, Public Library

S28 http://www.met.fu-berlin.de/wetterpate/historie/. Accessed 1 July 2009

\section{Published references}

Alcoforado MJ, Nunes F, Garcia JC, Taborda JP (2000) Temperature and precipitation reconstruction in southern Portugal during the late maunder minimum (AD 1675-1715). Holocene 10: 333-340

Amaral I (1968) As inundações de 25-26 de Novembro de 1967 na região de Lisboa. FinisterraRevista Portuguesa de Geografia III5:79-84

Amberg B (1890) Beiträge zur Chronik der Witterung und verwandter Naturerscheinungen mit besonderer Rücksicht auf das Gebiet der Reuss und der angrenzenden Gebiete der Aare und des Rheines. Beilage zum Jahresbericht für die Höhere Lehranstalt Luzern. Luzern

Assmann J (1992) Das Kulturelle Gedächtnis. Beck, München

Azevêdo TM, Nunes E, Ramos C (2004) Some morphological aspects and hydrological characterization of the Tagus Floods in the Santarém Region, Portugal. Nat Hazards 31:587-601

Bärring L, von Storch H (2004) Scandinavian storminess since about 1800. Geophys Res Lett 31:L20202

Bärring L, Fortuniak K (2009) Multi-indices analysis of southern Scandinavian storminess 1780-2005 and links to interdecadal variations in the NW Europe-North Sea region. Int J Climatol 29:373384

Belly L (ed) (1996) Dictionnaire de l'Ancien Régime. Presses Universitaires de France, Paris

Belo A (2004) Notícias impressas e manuscritas em Portugal no século XVIII. Horizontes de leitura da Gazeta de Lisboa. Horizontes Antropológicos (Porto Alegre) 22(Julho/Dez):15-35

Bohun R (1671) A discourse concerning the origine and properties of wind with an historicall account of hurricanes, and other tempestuous winds. Hall, Oxford

Boissiere J (2005) Chablis et tempêtes en forêt de Fontainebleau XVIIIe siècle. In: Corvol A (ed) Tempêtes sur la forêt française. Harmattan, Paris, pp 133-146

Borst A (1981) Das Erdbeben von 1348. Ein historischer Beitrag zur Katastrophenforschung. Historische Zeitschrift 233:529-569

Bos CK, Ullberg S, 't Hart P (2005) The long shadow of disaster. Memory and politics in Holland and Sweden. Int J Mass Emerg Disasters 23:5-16 
Brayne M (2002) The greatest storm: Britain's night of destruction, November 1703. Sutton, Stroud

Brázdil R, Dobrovolný P (2000) Chronology of strong wind events in the Czech Lands during the 16th-19th centuries. IGUJ-Prace Geograficzne 107:65-70

Brázdil R, Dobrovolný P (2001) History of strong winds in the Czech Lands. Causes, fluctuations, impacts. Geogr Pol 74:11-27

Brázdil R, Dobrovolný P, Štekl J, Kotyza O, Valášek H, Jež J (2004) History of weather and climate in the Czech Lands VI. Strong winds. Masaryk University, Brno

Brázdil R, Pfister C, Wanner H, von Storch H, Luterbacher J (2005) Historical climatology in Europe-the state of the art. Clim Change 70:363-430

Brooks CEP (1954) The English climate. EUP, London

Burke P (1997) Varieties of cultural history. Polity, Cambridge

Bütler B (2008) Gnädige Herren, ländliche Untertanen und der "ausserordentliche Sturmwind”. Die Bewältigung des Orkans "Prisca" 1739 in Basel. BA Thesis, University of Bern,Bern

Carolino L (2003) Ciência, Astrologia e Sociedade. A teoria da influência celeste em Portugal (15931755). Fundação Calouste Gulbenkian, Lisbon

Champion M (1864) Les inondations en France depuis le VIe siècle jusqu' à nos jours. Thunot, Paris

Corvol A (ed) (2005) Tempêtes sur la forêt française XVIe-XXe siècle. Harmattan, Paris

Dampier W (1699) Discourse of trade-winds, breezes, storms, seasons of the year, tides and currents of the torrid zone throughout the world. Vol. II, Part III: Voyages and descriptions. Knapton, London

Daniel U (2006) Kompendium Kulturgeschichte, 5th edn. Frankfurt/M

Daveau S, Almeida G, Feio M et al (1978) Os temporais de Fevereiro/Março de 1978. FinisterraRevista Portuguesa de Geografia XIII 26:236-260

de Kraker AMJ (1999) A method to assess the impact of high tides, storms and storm surges as vital elements in climatic history. The case of stormy weather and dikes in the northern part of Flanders, 1488 to 1609 . Clim Change 43:287-302

de Kraker AMJ (2005) Reconstruction of storm frequency in the North Sea Area of the preindustrial period, 1400-1625 and the connection with reconstructed time series of temperatures. His Meteorol 2:51-69

Defoe D (1704) The Storm: or, a collection of the most remarkable casualties and disasters which happen'd in the late dreadful tempest by both Sea and Land [republished in: Hamblyn R (ed) (2003) The storm. Penguin, London]

Démarée G, Muir-Wood R (2009) De "Grote Storm van december 1703" in de Lage Landen-een stormachtige periode in de Spaanse Successieoorlog, Jaarboek voor Ecologische Geschiedenis 2008:33-54

Dessert D (1996) La Royale, vaisseaux et marins du Roi-Soleil. Fayard, Paris

Dobrovolný P, Brázdil R (2003) Documentary evidence on strong winds related to convective storms in the Czech Republic since AD 1500. Atmos Res 67-68:95-116

Doll D (1991) Les cataclysmes éoliens dans les forêts d'Europe. Forêt Entreprise 5:8-9

Erb W, Odenthal-Kahabka J, Püttmann W (2004) Orkan "Lothar". Bewältigung der Sturmschäden in den Wäldern Baden-Württembergs. Dokumentation, Analyse, Konsequenzen. Forstliche Versuchs- und Forschungsanstalt Baden-Württemberg, Freiburg i.B

Evelyn J (1706) Silva: Or a discourse on forest-trees, and the propogation of timber in His Majesty's Dominions, 4th edn. Scott, London

Favier R (ed) (2002) Les pouvoirs publics face aux risques naturels dans l'histoire. MSH-Alpes, Grenoble

Favier R (2007) From solidarity to individual compensation. Assistance mechanisms faced with the emergence of liberalism in France during the 18th century. In: Favier R, Pfister C (eds) Solidarité et assurance. Les sociétés européennes face aux catastrophes (17e-21e s.). MSH, Grenoble, pp 57-80

Fink AH, Brücher T, Ermert V, Krüger A, Pinto JG (2009) The European storm Kyrill in January 2007: synoptic evolution, meteorological impacts and some considerations with respect to climate change. Nat Hazards Earth Syst Sci 9:405-423

Fonseca T (2001) Triste e Alegre Cidade de Évora. Testemunho de um anónimo do século XVIII. Estudo e transcrição. Colecção "Novos estudos Eborenses”. C.M.E., Évora

Freeman PK, Martin LA, Mechler R et al (2002) Catastrophes and development. Integrating natural catastrophe into development planning. Disaster Risk Management Working Paper Series No. 4. The World Bank, Washington

Fromm W (1981) Chronik der Gemeinde Elm. Gesammelt und bearbeitet bis zum Gedenkjahr an den Bergsturz. Gemeinde Elm, Elm 
García-Herrera R, Können GP, Wheeler D et al (2005a) CLIWOC: a climatological database for the world's oceans 1750-1854. Clim Change 73(1-2):1-12

García-Herrera R, Wilkinson C, Koek FB et al (2005b) Description and general background to ships' logbooks as a source of climatic data. Clim Change 73(1-2):13-36

Garnier E (2000) The Vosgian Forests tested by storms under the Old Regime (17th-18th Centuries). Revue Géographique de l'Est 40(3):133-139

Garnier E (2004a) Quatre siècles de tempêtes en forêt. Les phénomènes éoliens majeurs en France entre les XVIe et XIXe siècles. Rendez-Vous Techniques (Office National des Forêts) 3:16-21

Garnier E (2004b) Terre de conquêtes. La forêt vosgienne sous l'Ancien Régime. Fayard, Paris

Garnier E (2007) La ville face aux caprices du fleuve. L'exemple normand XVIe-XVIIIe siècle. Revue Urbaine 18:41-60

Golinski J (2001) Exquisite atmography. Theories of the world and experiences of the weather in a diary of 1703. Br J Hist Sci 34:149-171

Gottschalk MKE (1971-1977) Stormvloeden en revieroverstromingen in Nederland, 3 vols. Van Gorcum, Assen

Halbwachs M (1950) La Mémoire collective. Presse Universitaire, Paris

Hallegatte S, Hourcade JC, Ambrosi P (2007) Using climate analogues for assessing climate change economic impacts. Clim Change 82:47-60

Hamblyn R (2003) Introduction. In: Hamblyn R (ed) The storm. Penguin, London, pp x-x 1 [original work: Defoe D (1704) The storm: or, a collection of the most remarkable casualties and disasters which happen'd in the late dreadful tempest by both Sea and Land]

Huhn M (1987) Zwischen Teuerungspolitik und Freiheit des Getreidehandels: Staatliche und städtische Massnahmen in Hungerkrisen 1770-1847. In: Teuteberg HJ (ed) Durchbruch zum modernen Massenkonsum. Coppenrath, Münster, pp 37-90

Husson JP, Weisrock A (2000) L'ouragan du 26 décembre 1999 dans l'Est de la France. Revue Géographique de l'Est 40(3):26-47

Jones S, Harr P, Abraham J et al (2003) The extratropical transition of tropical cyclones. Forecast challenges, current understanding and future directions. Weather Forecast 18:1052-1092

Juneja M, Mauelshagen F (2007) Disasters and pre-industrial societies. Historiographic trends and comparative perspectives. Mediev Hist J 10(1-2):1-31

Kempe M (2003) Noah's flood. The genesis story and natural disasters in early modern times. Environ Hist 9(2):151-171

Krämer D (2009) Als die Buchen und Tannen "wie Vögelein" flogen. Die Winterstürme "Marcellus" und "Prisca" am 16. und 18. Januar 1739 und ihre Auswirkungen in der Zentralschweiz. Geschichtsfreund 162:143-176

Lamb HH, Frydendahl K (1991) Historic storms of the North Sea, British Isles and Northwest Europe. Cambridge University Press, Cambridge

Lisboa JL, Miranda T, Olival F (2002-2005) As Gazetas Manuscritas da Biblioteca Pública de Évora, vol. 1 (1729-1731), vol. 2 (1732-1734). Colibri, Lisboa

Lubbock B (1934) Barlow's journal of his life at sea in the Kings' ships, 1678-1703, 2 vols. Hurst and Blackett, London

Ludlum DM (1963) Early American hurricanes 1492-1870. American Meteorological Society, Boston

Luterbacher J, Xoplaki E, Dietrich D, Rickli R, Jacobeit J, Beck C, Gyalistras D, Schmutz C, Wanner $\mathrm{H}$ (2002) Reconstruction of sea-level pressure fields over the Eastern North Atlantic and Europe Back to 1500. Clim Dynam 18:545-561

Matulla C, Schöner W, Alexandersson H, von Storch H, Wang XL (2008) European storminess: late 19th century to present. Clim Dynam 31:1125-1130

Mauch C (2009) Introduction. In: Mauch C, Pfister C (eds) Natural disasters, cultural responses. Case studies towards a global environmental history. Lexington, Lanham, pp 1-16

Mauelshagen F (2009) Disaster and political culture in Germany since 1500. In: Mauch C, Pfister C (eds) Natural disasters, cultural responses. Lexington, Lanham, pp 41-75

Miranda T (2005) Manual de edição das Gazetas Manuscritas da Biblioteca Pública de Évora, Cultura, Centro de História da Cultura. UNL 21:325-361

Münchener Rück (ed) (1993) Winterstürme in Europa. Schadenanalyse 1990. Schadenpotentiale. Münchener Rückversicherungs-Gesellschaft, München

Nora P (1997) Les Lieux de Mémoire, 3 vols. Gallimard, Paris

Nunes MF (2004) The history of science in Portugal (1930-1940): the sphere of action of a scientific community. eJournal of Portuguese History 2(2). www.brown.edu/Departments/Portuguese Brazilian_Studies/ejph/ 
Parry ML, Canziani OF, Palutikof JP (eds) (2007) Climate change: impacts, adaptation and vulnerability. Contribution of working group II to the fourth assessment report of the Intergovernmental Panel on Climate Change. Cambridge University Press, Cambridge UK

Pfister C (1998) Raum-zeitliche Rekonstruktion von Witterungsanomalien und Naturkatastrophen 1496-1995. Schlussbericht NFP 31. VdF, Zürich

Pfister C (1999) Wetternachhersage. 500 Jahre Klimavariationen und Naturkatastrophen 1496-1995. Paul Haupt, Bern

Pfister C (2001) Klimawandel in der Geschichte Europas. Zur Entwicklung und zum Potenzial der Historischen Klimatologie. OÉZG, OÉsterr Z Gesch.Wiss 12(2):7-43

Pfister C (2002) Strategien zur Bewältigung von Naturkatastrophen seit 1500. In: Pfister C (ed) Am Tag danach. Zur Bewältigung von Naturkatastrophen in der Schweiz 1500-2000. Haupt, Bern, pp 209-254

Pfister C (2009) Learning from nature-induced disasters. Theoretical considerations and case studies from Western Europe. In: Mauch C, Pfister C (eds) Natural disasters, cultural responses. Case studies towards a global environmental history. Lexington, Lanham, pp 17-40

Pfister C, Luterbacher J, Wanner H, Wheeler D, Brázdil R, Ge Q, Hao Z, Moberg A, Grab S, Rosario del Prieto M (2009) Documentary evidence as climate proxies. PAGES (Past Global Changes). http://www.pages-igbp.org/cgi-bin/WebObjects/products.woa/wa/product?id=331

Pinto JG, Zacharias S, Fink AH, Leckebusch GC, Ulbrich U (2009) Factors contributing to the development of extreme North Atlantic cyclones and their relationship with the NAO. Clim Dynam 32:711-737

Poirrier P (2004) Les enjeux de l'histoire culturelle. Seuil, Paris

Puyo JI (2005) L'interpretation sylvicole des chablis XVIIe-XX siècle. In: Corvol A (ed) A Tempêtes sur la forêt française. Harmattan, Paris, pp 103-118

Rohr C (2007) Extreme Naturereignisse im Ostalpenraum. Naturerfahrung im Spätmittelalter und am Beginn der Neuzeit. Böhlau, Köln

Riggenbach A (1891) Collectanea zur Basler Witterungsgeschichte. Reinhard, Basel

Roxo MJ, Ventura J (1986) As inundações catastróficas de novembro de 1983 na região de LisboaLoures. Estudos em homenagem a Mariano Feio 36:391-405

Schenk GJ, Engels JI (eds) (2007) Historical disaster research. Concepts, methods and case-studies. Hist Soc Res (Special Issue) 32(3)

Schiesser HH, Pfister C, Bader J (1997) Winter storms in Switzerland North of the Alps 1864/651993/94. Theor Appl Climatol 58:1-19

Schraft A, Durand E, Hausmann P (1993) Stürme über Europa. Schäden und Szenarien. Schweizer Rückversicherungs-Gesellschaft, Zürich

Schüepp M, Schiesser HH, Huntrieser H et al (1994) The winterstorm "Vivian" of 27 February 1990. About the meteorological development, wind forces and damage situation in the forests of Switzerland. Theor Appl Climatol 49:183-200

Schwarz-Zanetti G, Pfister C, Müller F (1997) "Der schne den pferden bis an bauch gienge". Schneebedeckung und Spätfröste im zentralen Schweizer Mittelland in den Jahren 1730-1760. Argovia 107:99-128

Schweizerische Rückversicherungs-Gesellschaft (ed) (2007) Natur- und Man-made-Katastrophen im Jahr 2006. Sigma 2. Swiss Re, Zürich

Stern N (2006) The Stern review on the economics of climate change. http://www.hm-treasury. gov.uk

Taborda JP (2006) O temporal de 3 a 6 de Dezembro de 1739 em Portugal - reconstituição através de fontes documentais descritivas. Finisterra-Revista Portuguesa de Geografia XLI 82:73-86

Torres X (2000) Els llibres de familia de pagès. Memòries de pagès, memòries de mas (segles XVIXVIII). Biblioteca d'historia rural, Girona

Trevelyan GM (1930) England under Queen Anne. Part 1-Blenheim. Longmans, London

Ulbrich U, Fink AH, Klawa M, Pinto JG (2001) Three extreme storms over Europe in December 1999. Weather 56:70-80

Ulbrich U, Leckebusch GC, Pinto JG (2009) Extra-tropical cyclones in the present and future climate: a review. Theor Appl Climatol 96:117-131

Usbeck T, Wohlgemuth T, Dobbertin M, Pfister C, Bürgi A, Rebetez M (2010) Increasing storm damage to forests in Switzerland from 1858 to 2007. Agric For Meteorol 150:47-55

Wang X, Zwiers FW, Swail VR, Feng Y (2009) Trends and variability of storminess in the Northeast Atlantic Region, 1874-2007. Clim Dynam 33:1179-1195

Wernli H, Dirren S, Liniger MA (2002) Dynamical aspects of the lifecycle of the winter storm "Lothar" (24-26 December 1999). Quart J Roy Meteor Soc 128:405-429 
Wheeler D (2003) The Great Storm of November 1703. A new look at the seamens' records. Weather 58:419-427

Wheeler D, Suarez-Dominguez J (2006) Climatic reconstructions for the northeast Atlantic region AD1685-1700. A new source of evidence from naval logbooks. Holocene 16:39-49

Wheeler D, Garcia-Herrera R, Wilkinson W, Ward C (2009) Atmospheric circulation and storminess derived from Royal Navy logbooks: 1685 to 1750. Clim Change. doi:10.1007/s10584-009-9732-x

WSL (Eidg. Forschungsanstalt), BUWAL (Bundesamt für Umwelt, Wald und Landschaft) (eds) (2001) Lothar. Der Orkan 1999. Ereignisanalyse. WSL, Birmensdorf 